\title{
Reliability and Validity of a Chinese Version of the STEM Attitude Scale for Primary and Secondary School Students
}

\author{
Yanjun Zhang ${ }^{1}$, Qianqian $\mathrm{Xu}{ }^{1}$, Jinghua Lao ${ }^{1}$ and Yan Shen ${ }^{2, *}$ \\ 1 College of Teacher Education, Zhejiang Normal University, Jinhua 321004, China; zhyj@zjnu.cn (Y.Z.); \\ zhejiangxuqq@163.com (Q.X.); zhejianglaojinghua@163.com (J.L.) \\ 2 School of Humanities, Huzhou University, Huzhou 313000, China \\ * Correspondence: huzhoushenyan@163.com
}

check for

updates

Citation: Zhang, Y.; Xu, Q.; Lao, J.; Shen, Y. Reliability and Validity of a Chinese Version of the STEM Attitude Scale for Primary and Secondary School Students. Sustainability 2021, 13, 12661. https://doi.org/10.3390/ su132212661

Received: 23 September 2021 Accepted: 11 November 2021 Published: 16 November 2021

Publisher's Note: MDPI stays neutral with regard to jurisdictional claims in published maps and institutional affiliations.

Copyright: (c) 2021 by the authors. Licensee MDPI, Basel, Switzerland. This article is an open access article distributed under the terms and conditions of the Creative Commons Attribution (CC BY) license (https:/ / creativecommons.org/licenses/by/ $4.0 /)$.

\begin{abstract}
In recent years, STEM (science, technology, engineering, mathematics) education has received widespread attention from all over the world, and there are not many studies on STEM attitudes in China. One of the reasons is the lack of measurement tools that have been tested for reliability and validity. The Chinese version STEM attitudes scale for primary and secondary schools is a multidimensional scale that measures the STEM attitudes of primary and secondary school students. It consists of three subscales: STEM interest, 21st-century skills confidence, and STEM career interest. In order to test the reliability and validity of the scale application, as well as understand and improve the STEM attitudes of primary and secondary school students, the research team surveyed and collected 566 responses from primary and secondary school students in Zhejiang, Shanghai, Shandong, Liaoning, and other places. After exploratory factor analysis, confirmatory factor analysis, and a reliability and validity test, the scale finally retained 48 items. The scale supports a hypothetical five-factor model with good reliability and validity and can be used to assess STEM attitudes in Chinese primary and secondary schools. This research also shows that students' STEM interests and STEM career interests showed clear variation among different genders, grades, and parental education levels.
\end{abstract}

Keywords: STEM attitude; evaluation scale; reliability; validity; primary and secondary school students

\section{Introduction}

In recent years, STEM (science, technology, engineering, mathematics) education has attracted widespread attention all over the world [1]. With the in-depth development of the knowledge economy, the demand for STEM skills and green jobs has surged in more and more countries. The Programme for International Student Assessment (PISA) 2018 evaluation results released in December 2019 show that Chinese 15-year-old students rank first in mathematics and science literacy in the participating countries (regions) [2]. However, similar to many other countries, Chinese primary and secondary school students also show a decline in STEM interest as grade level increases [3].

This has caused increased attention to STEM education in China, along with research on STEM education in China. However, normative empirical research is rare, especially empirical research on the STEM attitudes of primary and secondary school students. STEM attitude refers to students' STEM interest, 21st-century skill confidence, and STEM career interest [4]. Eric Wiebe's research team holds this view. According to the present study, these three elements contained in STEM attitude can also be applied to Chinese practice. Discipline attitude refers to the relatively stable evaluation and behavioural tendencies of a subject formed in the course of learning [5]. Students' attitude towards a certain discipline may be composed of their self-efficacy and expectation value [6].

Self-efficacy is positively associated with interest, and both influence and promote each other [7]. It can be said that STEM interest affects students' STEM self-efficacy and 
is an important part of their STEM attitude. Meanwhile, since the PISA assessment released the 2018 global competency framework, 21st-century skills such as critical thinking, cross-cultural communication and problem solving have attracted more and more attention. These skills are the core qualities that STEM education should have for compound innovative talents cultivated in the 21st century. It can be seen that students' self-efficacy (or confidence) in 21st-century skills can also be a part of their STEM attitude.

Students' STEM professional interest reflects their expectations for their future career and can also be used as a part of students' STEM attitude. Studies have shown that high school students' career interest will affect their college STEM curriculum choice, and after that their career choice [8]. In fact, according to the data centre of the Ministry of Education, only $50.2 \%$ of junior high school students in China can enter ordinary high schools every year, and nearly half of the remaining students enter vocational high schools or take a job. Their STEM career interests also affect their career and major choices.

It can be seen that the research on STEM attitudes of primary and secondary school students is particularly important, but the relevant research in China is not common. One of the main reasons is a lack of measurement tools that have been tested for reliability and validity. International scholars have developed many STEM education evaluation scales, which can be roughly divided into three categories: first is the interest in STEM careers scale, which is used to investigate the possibility of primary and secondary school students engaging in STEM careers in the future [9]; the second is the STEM project attitude scale, which is used to investigate high school students' attitude towards STEM projects [10]; the third category is the STEM attitude scale for primary and secondary school students, which is used to measure STEM interest, 21st-century skill self-confidence, and the STEM career orientation of fourth and fifth grade primary and secondary school students [11]. However, the scales related to STEM education developed by domestic scholars started late, are small in number, and are mostly used to measure STEM project learning, such as the student STEM project learning ability evaluation scale [12] and the student participation measurement scale in project-based STEM teaching [13].

The scale focusing on STEM attitudes of primary and secondary school students has not been found. Some scholars pointed out that there are few tools to measure multidisciplinary attitudes on the same scale, and the evaluation instruments that can accurately measure learners' interdisciplinary STEM attitudes towards STEM courses or projects are very limited [14]. Therefore, the objectives of the current study are as follows: Once authorization from the scale developer has been received, the research team will introduce the STEM Attitude Scale to the Chinese context and test its reliability and validity there so as to help understand the basic STEM attitudes of Chinese primary and secondary school students.

\section{Literature Review}

The S-STEM survey invites students to give information about their attitudes toward science, technology, engineering, and mathematics subjects; post-secondary pathways; and career interests. Chinese scholars have concentrated their research on STEM learning scales for primary and secondary school students, and most of the evaluation scales are designed for evaluating students' performance in a STEM classroom $[13,15,16]$. Many scholars generally believe that the degree and duration of students' learning participation have an important impact on students' learning efficiency [17]. Therefore, Chinese scholars and teachers have paid great attention to students' STEM classroom input. STEM learning is a team learning method in which students are the main actors and teachers have the role of guide. In teaching practice, results are generally submitted and presented as a group, so that each student can contribute to the results of his or her own team [18]. Establishing a scale for students' STEM learning evaluation, including self-evaluation, teacher evaluation, and peer evaluation, can promote and stimulate creative and in-depth STEM learning [19]. Studies of self-efficacy are generally concentrated in secondary school, while self-efficacy scales are very rare in primary school $[20,21]$. Many other scholars have used Bian Yufang's Learning 
Self-Efficacy Scale [22], or other scales from foreign research, in relation to their own research direction. A few people have begun to focus on STEM learning attitudes of primary and secondary school students and designed a STEM Learning Attitude Scale $[14,23]$. However, there are few tools for measuring multidisciplinary attitudes on one scale, and there are very limited measures of the evaluation of interdisciplinary STEM attitudes for learners of STEM courses or projects [14].

Viewed from a much larger scale, students' STEM learning-related scales mostly have a certain empirical test. Initially, there are some tools to measure students' attitudes toward a single STEM subject, but which does not include all disciplines. For example, the Test of Science-Related Attitudes consists of seven subscales (10 items each) measuring high school students' attitudes toward science [24], and the Affective Elements of Science Learning Questionnaire measures students' attitudes toward science, which consists of four subscales (35 items total) [25]. Also, the Attitudes Toward Maths Survey aims to measure students attitudes toward mathematics [26]. With scientific and technological developments in recent years, many scholars have realized the importance of STEM education; hence, ways to measure students' STEM attitudes is also particularly important. International scholars have developed numerous S-STEM scales to measure students' attitudes towards STEM. A survey created by Erkut and Marx in 2005 measures attitudes toward multiple STEM subjects: science, mathematics, and engineering. Erkut and Marx found Cronbach's alpha levels to be above 0.85 for the science and mathematics attitudes constructs and above 0.80 for the engineering attitudes construct. The instrument provided a set of items from which to build a more reliable, valid, and fair survey [27]. Based on the framework of Erkut and Marx's S-STEM in 2005, the Student Learning Conditions Survey, and the Bureau of Labor Statistics' Occupational Outlook Handbook [1], Wiebe et al. developed an upgraded SSTEM. Exploratory factor analysis (EFA) and confirmatory factor analysis (CFA) were used to ensure the validity of the scale structure. Cronbach's alpha was used to measure internal consistency reliability for each of the four constructs [4]. In addition, the Friday Institute developed an S-STEM based on the following sources: mathematics attitudes, science attitudes, and engineering and technology attitudes (which were constructs adapted from a survey developed for an engineering programme at a girls' middle school) [27]; the Bureau of Labor Statistics' Occupational Outlook Handbook, which further developed the careers section [1]; and the Friday Institute's Student Learning Conditions Survey from which the 21st-century learning attitudes construct was adapted [28]. Consequently, two versions have been developed: one for 4th and 5th graders (the "Upper Elementary S-STEM"), and one for 6th-12th graders (the "Middle/High School S-STEM") [29], which is more accurate and scientific. In 2015, Yildirim and Selvi adapted the Sources of Middle School Maths STEM Attitude Scale developed by Faber et al. [11] for the Turkish context. Exploratory and confirmatory factor analyses were conducted to investigate the structural validity of the scale and test the structure's theoretical basis of the adapted scale, respectively. Also, some descriptive analyses were conducted, indicating that there is a good model-data fit [30]. In addition, a study by Benek and Akcay in 2019 was conducted to develop a valid and reliable attitude scale that could measure secondary school students' attitudes towards STEM in Turkey [31]. Exploratory factor analysis (EFA) and confirmatory factor analysis (CFA) were also adopted to test the validity of the scale structure, and the results of the CFA were used to determine the model fit of the scale. The results showed that all values were within acceptable limits. Finally, a valid and reliable scale was formed, including 33 items and 6 factors.

To sum up, there is little research that focuses on STEM attitudes of primary and secondary students in China, and relevant scales are seen more in other countries. Therefore, our research team took various factors into consideration, such as targets applicability, universality, and so on, and finally tested the revised S-STEM scale from the Eric Wiebe research team at North Carolina State University to develop a valid and reliable attitude scale to learn the attitudes of primary and secondary students in China. 


\section{Method}

The purpose of this study is to test the reliability and validity of the Chinese version of the STEM Attitude Scale in Chinese primary and secondary students, to provide the basis for understanding the basic situation of STEM attitudes of Chinese primary and secondary students, and to provide an effective measurement tool for China to study STEM attitudes of primary and secondary students in the future. The research team translated, revised, and tested the reliability and validity of the Chinese version of the STEM attitude scale for primary and secondary school students.

\subsection{Subjects and Evaluating Process}

Judgement sampling was conducted in choosing regions and suitable students. In China, Liaoning represents the northern province, Shandong can be regarded as the province in middle areas, and Zhejiang is located in the south. Shanghai and Zhejiang have participated in PISA as more developed regions, while the less developed areas of Shandong and Liaoning have not. In each of the above-mentioned regions, the research team mainly used random sampling to obtain students. In primary schools, we also used judgement sampling to survey fourth and fifth graders since they are better able to read the questionnaire and provide answers. In addition, we did not ask the sixth graders to fill in the questionnaires since some primary schools do not include a sixth grade. We included all junior middle school students and chose participants randomly from all three grades. The research team used the questionnaire survey method, using both paper and online questionnaire survey tools, and randomly surveyed the primary and secondary school students in Zhejiang, Shanghai, Shandong, Liaoning, and other areas from April to June 2019. Before filling in the questionnaire, the participants were informed of the research background, purpose, and significance of this study in the form of an oral statement or an informed consent form. We stated clearly that we promised to use their anonymous answers only for research purposes. They were told they had the freedom to stop filling in the forms at any time, and they could go on answering the questions if they agreed to do so.

A total of 651 questionnaires were received (244 paper questionnaires and 407 online questionnaires). Participants voluntarily consented to participate in this study and answer the questions. All informants' names are anonymous. Missing values were handled with listwise deletion. After deleting 85 questionnaires that met the characteristics of missing, over-filled, and regular responses, 566 questionnaires were valid (232 paper questionnaires and 334 online questionnaires). The recovery rate of paper questionnaires was $95.08 \%$ and that of online questionnaires was $82.06 \%$. In all, there were 566 primary and secondary school students, including 261 boys and 305 girls: 168 in grade 4, 90 in grade 5, 21 in grade 7, 168 in grade 8 , and 119 in grade 9 . There were 330 guardians with the highest education level below bachelor's degree, 191 guardians with a bachelor's degree, 29 guardians with a master's degree, and 16 with a doctoral degree. This is shown in Table 1.

Table 1. Demographic Information $(n=566)$.

\begin{tabular}{cccc}
\hline Categories & Items & Frequency & Percentage (\%) \\
\hline \multirow{2}{*}{ Gender } & Male & 261 & 46.11 \\
& Female & 305 & 53.89 \\
& 4th (Primary) & 168 & 29.68 \\
Grades & 5th (Primary) & 90 & 15.90 \\
& 7th (Junior high) & 21 & 3.71 \\
& 8th (Junior high) & 168 & 29.68 \\
Parents' highest & 9th (Junior high) & 119 & 21.02 \\
education level & Below bachelor's degree & 330 & 58.30 \\
& Bachelor's degree & 191 & 33.57 \\
& Master's degree & 29 & 5.12 \\
\hline
\end{tabular}




\subsection{Instruments}

With the authorization of Professor Eric Weber, the research team translated the original STEM attitude scale for primary school students into Chinese. Firstly, the researcher and a full-time translator jointly translated the English version into Chinese, and then the other two professional English translators whose mother tongue is Chinese translated the translated Chinese first draft back into English. For disputed areas, the authors discussed and revised the first Chinese version with two researchers who hold a $\mathrm{PhD}$ in education to finally form the STEM attitude scale for primary and secondary school students. The scale consists of three subscales. Of these, the STEM interest scale consists of 26 items in three subdimensions: mathematics interest ( 8 items), science interest (9 items), and engineering/technology interest (9 items). A Likert five-point scale was adopted ( $1=$ strongly disagree, $5=$ strongly agree). After the positive treatment of negative questions, the higher the score, the higher the students' interest in STEM. The 21st-century skill confidence scale consists of 11 items, which also adopts Likert five-point scoring ( $1=$ strongly disagree, $5=$ strongly agree). There is no reverse scoring. The higher the score, the more confident students are about 21st-century skills. The STEM career interest scale consists of 12 items, such as animal scientist, biomedical engineer, doctor, and surgeon. Likert four-point scoring is adopted. The higher the score, the higher the student's STEM career interest.

From the perspective of career planning, the age and gender of students will affect their interest in STEM careers. Studies have pointed out that students' interest in STEM careers fluctuates with age and shows a declining trend [32]. Other studies have found that girls' overall attitudes toward STEM subjects are either less positive than boys' or decline more significantly with age [33]. From the social perspective, students' STEM learning attitudes and related career choices are closely related to their family environment. Parents' educational background, occupation, and education mode will all have an impact on students' STEM career choice. Therefore, this study also analyses the influence of gender, grade, and parents' highest education level on students' STEM interest, 21st-century skill confidence, and STEM career interest.

\subsection{Statistical Analysis}

Using SPSS 23.0 statistical software, the data were analysed by item analysis, independent sample $t$-test, reliability test, EFA and one-way ANOVA; Amos 24.0 was used for CFA to determine whether the five-factor structure model is consistent with the Chinese version of the STEM attitude scale for primary and secondary school students.

\section{Results and Analysis}

\subsection{Project Analysis}

The researchers used "critical ration" for project analysis. According to the total score of the STEM attitude scale for primary and secondary school students, the first $27 \%$ of the scores are high, and the last $27 \%$ are low. An independent sample $t$-test was conducted for the difference of scores on each item in the high and low groups. The absolute value of the $t$ values of each item was between 6.907 and 22.287. There was significant difference between the two groups in all items $(p<0.01)$, indicating that the 49 items of the questionnaire had high discrimination, reliability, and effectiveness, as shown in Table 2. Therefore, the project analysis did not delete any items and continued to the next analysis. 
Table 2. Analysis of items in the STEM attitudes scale for primary and secondary school students.

\begin{tabular}{|c|c|c|c|c|c|c|c|c|}
\hline \multirow{2}{*}{ I $\bar{x}$ Tems } & \multicolumn{4}{|c|}{ T Test for the Equality of Means } & \multirow{2}{*}{ Group } & \multirow{2}{*}{$\mathbf{n}$} & \multirow{2}{*}{$\bar{x}$} & \multirow{2}{*}{$\mathbf{s}$} \\
\hline & $\mathbf{t}$ & df & $\mathrm{p}$ & Mean Deviation & & & & \\
\hline \multirow{2}{*}{ M1 } & -8.932 & 318 & 0.00 & -1.188 & low & 162 & 3.16 & 1.256 \\
\hline & & & & & high & 158 & 4.35 & 1.117 \\
\hline \multirow{2}{*}{ M2 } & -9.541 & 318 & 0.00 & -1.175 & low & 162 & 2.40 & 1.059 \\
\hline & & & & & high & 158 & 3.57 & 1.142 \\
\hline \multirow{2}{*}{ M3 } & -8.155 & 309.909 & 0.00 & -1.106 & low & 162 & 2.92 & 1.126 \\
\hline & & & & & high & 158 & 4.03 & 1.292 \\
\hline \multirow{2}{*}{ M4 } & -14.35 & 318 & 0.00 & -1.693 & low & 162 & 2.61 & 1.059 \\
\hline & & & & & high & 158 & 4.30 & 1.051 \\
\hline \multirow{2}{*}{ M5 } & -7.300 & 318 & 0.00 & -0.977 & low & 162 & 3.35 & 1.177 \\
\hline & & & & & high & 158 & 4.33 & 1.218 \\
\hline \multirow{2}{*}{ M6 } & -15.570 & 318 & 0.00 & -1.784 & low & 162 & 2.21 & 1.024 \\
\hline & & & & & high & 158 & 3.99 & 1.025 \\
\hline \multirow{2}{*}{ M7 } & -16.528 & 307.347 & 0.00 & -1.764 & low & 162 & 2.70 & 1.052 \\
\hline & & & & & high & 158 & 4.46 & 0.849 \\
\hline \multirow{2}{*}{ M8 } & -15.471 & 318 & 0.00 & -1.720 & low & 162 & 2.45 & 1.034 \\
\hline & & & & & high & 158 & 4.17 & 0.952 \\
\hline \multirow{2}{*}{ S1 } & -15.233 & 318 & 0.00 & -1.544 & low & 162 & 2.99 & 0.997 \\
\hline & & & & & high & 158 & 4.53 & 0.803 \\
\hline \multirow{2}{*}{$\mathrm{S} 2$} & -14.356 & 318 & 0.00 & -1.531 & low & 162 & 2.49 & 0.947 \\
\hline & & & & & high & 158 & 4.02 & 0.961 \\
\hline \multirow{2}{*}{ S3 } & -17.672 & 318 & 0.00 & -1.723 & low & 162 & 2.80 & 0.960 \\
\hline & & & & & high & 158 & 4.52 & 0.771 \\
\hline \multirow{2}{*}{ S4 } & -15.384 & 318 & 0.00 & -1.587 & low & 162 & 2.93 & 1.055 \\
\hline & & & & & high & 158 & 4.51 & 0.763 \\
\hline \multirow{2}{*}{ S5 } & -16.770 & 318 & 0.00 & -1.708 & low & 162 & 2.71 & 0.989 \\
\hline & & & & & high & 158 & 4.42 & 0.823 \\
\hline \multirow{2}{*}{ S6 } & -14.731 & 318 & 0.00 & -1.510 & low & 162 & 2.64 & 0.917 \\
\hline & & & & & high & 158 & 4.15 & 0.916 \\
\hline \multirow{2}{*}{ S7 } & -18.068 & 318 & 0.00 & -1.769 & low & 162 & 2.61 & 0.907 \\
\hline & & & & & high & 158 & 4.38 & 0.842 \\
\hline \multirow{2}{*}{ S8 } & -7.238 & 298.974 & 0.00 & -0.906 & low & 162 & 3.29 & 0.982 \\
\hline & & & & & high & 158 & 4.20 & 1.239 \\
\hline \multirow{2}{*}{ S9 } & -16.138 & 318 & 0.00 & -1.747 & low & 162 & 2.26 & 0.943 \\
\hline & & & & & high & 158 & 4.01 & 0.994 \\
\hline \multirow{2}{*}{ ET1 } & -17.430 & 295.363 & 0.00 & -1.791 & low & 162 & 2.76 & 1.050 \\
\hline & & & & & High & 158 & 4.55 & 0.770 \\
\hline \multirow{2}{*}{ ET2 } & -15.822 & 318 & 0.00 & -1.654 & low & 162 & 2.83 & 1.029 \\
\hline & & & & & high & 158 & 4.49 & 0.827 \\
\hline
\end{tabular}


Table 2. Cont.

\begin{tabular}{|c|c|c|c|c|c|c|c|c|}
\hline \multirow{2}{*}{ I $\bar{x}$ Tems } & \multicolumn{4}{|c|}{ T Test for the Equality of Means } & \multirow{2}{*}{ Group } & \multirow{2}{*}{$\mathbf{n}$} & \multirow{2}{*}{$\bar{x}$} & \multirow{2}{*}{$\mathbf{s}$} \\
\hline & $t$ & df & $\mathrm{p}$ & Mean Deviation & & & & \\
\hline \multirow{2}{*}{ ET3 } & -15.983 & 318 & 0.00 & -1.744 & low & 162 & 2.38 & 0.952 \\
\hline & & & & & high & 158 & 4.12 & 0.999 \\
\hline \multirow{2}{*}{ ET4 } & -16.830 & 318 & 0.00 & -1.859 & low & 162 & 2.43 & 1.039 \\
\hline & & & & & high & 158 & 4.29 & 0.933 \\
\hline \multirow{2}{*}{ ET5 } & -15.642 & 318 & 0.00 & -1.690 & low & 162 & 2.52 & 0.967 \\
\hline & & & & & high & 158 & 4.22 & 0.967 \\
\hline \multirow{2}{*}{ ET6 } & -16.843 & 307.774 & 0.00 & -1.758 & low & 162 & 2.67 & 1.027 \\
\hline & & & & & high & 158 & 4.43 & 0.832 \\
\hline \multirow{2}{*}{ ET7 } & -18.461 & 282.706 & 0.00 & -1.726 & low & 162 & 2.91 & 0.983 \\
\hline & & & & & high & 158 & 4.63 & 0.662 \\
\hline \multirow{2}{*}{ ET8 } & -20.363 & 294.128 & 0.00 & -1.892 & low & 162 & 2.73 & 0.952 \\
\hline & & & & & high & 158 & 4.62 & 0.692 \\
\hline \multirow{2}{*}{ ET9 } & -16.590 & 318 & 0.00 & -1.697 & low & 162 & 2.53 & 0.913 \\
\hline & & & & & high & 158 & 4.23 & 0.916 \\
\hline \multirow{2}{*}{$\mathrm{C} 1$} & -17.758 & 318 & 0.00 & -1.622 & low & 162 & 2.83 & 0.875 \\
\hline & & & & & high & 158 & 4.45 & 0.753 \\
\hline \multirow{2}{*}{$\mathrm{C} 2$} & -16.397 & 262.098 & 0.00 & -1.467 & low & 162 & 3.18 & 0.977 \\
\hline & & & & & high & 158 & 4.65 & 0.576 \\
\hline \multirow{2}{*}{$\mathrm{C} 3$} & -22.287 & 291.676 & 0.00 & -1.830 & low & 162 & 2.78 & 0.847 \\
\hline & & & & & high & 158 & 4.61 & 0.605 \\
\hline \multirow{2}{*}{$\mathrm{C} 4$} & -15.786 & 231.717 & 0.00 & -1.352 & low & 162 & 3.41 & 0.982 \\
\hline & & & & & high & 158 & 4.77 & 0.468 \\
\hline \multirow{2}{*}{ C5 } & -16.434 & 233.750 & 0.00 & -1.469 & low & 162 & 3.27 & 1.022 \\
\hline & & & & & high & 158 & 4.74 & 0.494 \\
\hline \multirow{2}{*}{ C6 } & -14.621 & 245.754 & 0.00 & -1.313 & low & 162 & 3.36 & 1.008 \\
\hline & & & & & high & 158 & 4.68 & 0.533 \\
\hline \multirow{2}{*}{$\mathrm{C} 7$} & -18.528 & 253.707 & 0.00 & -1.566 & low & 162 & 3.10 & 0.937 \\
\hline & & & & & high & 158 & 4.67 & 0.523 \\
\hline \multirow{2}{*}{$\mathrm{C} 8$} & -18.684 & 266.838 & 0.00 & -1.565 & low & 162 & 3.09 & 0.908 \\
\hline & & & & & high & 158 & 4.65 & 0.552 \\
\hline \multirow{2}{*}{ C9 } & -17.487 & 318 & 0.00 & -1.576 & low & 162 & 3.00 & 0.919 \\
\hline & & & & & high & 158 & 4.58 & 0.671 \\
\hline \multirow{2}{*}{ C10 } & -15.756 & 280.261 & 0.00 & -1.405 & low & 162 & 3.26 & 0.943 \\
\hline & & & & & high & 158 & 4.66 & 0.624 \\
\hline \multirow{2}{*}{ C11 } & -18.079 & 232.235 & 0.00 & -1.531 & low & 162 & 3.24 & 0.970 \\
\hline & & & & & high & 158 & 4.77 & 0.464 \\
\hline
\end{tabular}


Table 2. Cont.

\begin{tabular}{|c|c|c|c|c|c|c|c|c|}
\hline \multirow{2}{*}{ I $\bar{x}$ Tems } & \multicolumn{4}{|c|}{ T Test for the Equality of Means } & \multirow{2}{*}{ Group } & \multirow{2}{*}{$\mathbf{n}$} & \multirow{2}{*}{$\bar{x}$} & \multirow{2}{*}{$\mathbf{s}$} \\
\hline & $\mathbf{t}$ & df & $\mathbf{p}$ & Mean Deviation & & & & \\
\hline \multirow{2}{*}{$\mathrm{J} 1$} & -16.660 & 318 & 0.00 & -1.395 & low & 162 & 2.09 & 0.844 \\
\hline & & & & & high & 158 & 3.48 & 0.636 \\
\hline \multirow{2}{*}{$\mathrm{J} 2$} & -16.970 & 317.651 & 0.00 & -1.330 & low & 162 & 2.04 & 0.721 \\
\hline & & & & & high & 158 & 3.37 & 0.681 \\
\hline \multirow{2}{*}{$\mathrm{J} 3$} & -14.142 & 309.056 & 0.00 & -1.203 & low & 162 & 2.27 & 0.833 \\
\hline & & & & & high & 158 & 3.47 & 0.683 \\
\hline \multirow{2}{*}{$\mathrm{J} 4$} & -6.907 & 311.076 & 0.00 & -0.732 & low & 162 & 2.17 & 0.886 \\
\hline & & & & & high & 158 & 2.90 & 1.004 \\
\hline \multirow{2}{*}{ J5 } & -16.042 & 318 & 0.00 & -1.400 & low & 162 & 2.04 & 0.837 \\
\hline & & & & & high & 158 & 3.44 & 0.718 \\
\hline \multirow{2}{*}{ J6 } & -9.707 & 318 & 0.00 & -0.939 & low & 162 & 2.36 & 0.889 \\
\hline & & & 0.00 & & high & 158 & 3.30 & 0.841 \\
\hline \multirow{2}{*}{ J7 } & -14.010 & 318 & 0.00 & -1.270 & low & 162 & 2.15 & 0.872 \\
\hline & & & & & high & 158 & 3.42 & 0.742 \\
\hline \multirow{2}{*}{ J8 } & -14.486 & 297.317 & 0.00 & -1.309 & low & 162 & 2.22 & 0.919 \\
\hline & & & & & high & 158 & 3.53 & 0.683 \\
\hline \multirow{2}{*}{ J9 } & -9.969 & 318 & 0.00 & -0.987 & low & 162 & 2.23 & 0.865 \\
\hline & & & & & high & 158 & 3.22 & 0.905 \\
\hline \multirow{2}{*}{$\mathrm{J} 10$} & -16.920 & 318 & 0.00 & -1.449 & low & 162 & 1.98 & 0.788 \\
\hline & & & & & high & 158 & 3.42 & 0.743 \\
\hline \multirow{2}{*}{ J11 } & -16.033 & 313.663 & 0.00 & -1.398 & low & 162 & 1.96 & 0.742 \\
\hline & & & & & high & 158 & 3.35 & 0.814 \\
\hline \multirow{2}{*}{$\mathrm{J} 12$} & -14.787 & 305.876 & 0.00 & -1.340 & low & 162 & 1.93 & 0.736 \\
\hline & & & & & high & 158 & 3.27 & 0.877 \\
\hline
\end{tabular}

Note: $\mathrm{M}$ is mathematics interest; $\mathrm{S}$ is science interest; $\mathrm{ET}$ is engineering/technology interest; $\mathrm{C}$ is 21st-century skill confidence; J is STEM career interest.

\subsection{Validity Test}

\subsubsection{Content Validity}

The content validity was assessed by a professional group composed of three STEM education research experts, three scholars with a PhD in curriculum and teaching theory, and two scholars holding a PhD in comparative education. Panel members scored the 49 items of the scale on a scale of 1 to 4 (1 for no correlation and 4 for strong correlation). According to the content validity index (CVI), for each item, the number of experts with a score of 3 or 4 is divided by the total number of experts. The average number of CVI of all items of the meter is the CVI of the total meter [34], which evaluates the content validity of the scale. The CVI of the Chinese STEM attitude scale was 0.928 (>0.7). The results show that the evaluation of the scale by the members of the expert group is consistent. Therefore, the content validity of the Chinese version of the STEM attitude scale for primary and secondary school students is good.

\subsubsection{Construct Validity}

The research team selected half of the data (283 copies) to conduct EFA on the Chinese version of the STEM attitude scale for primary and secondary school students. After a kmo 
adaptability test and Bartlett spherical test, the results showed that the kmo coefficient was 0.954; the Chi-square value was 11,257.066; the DF was $1128(p<0.001)$, which was statistically significant; and the data was suitable for EFA. Selecting "principal component analysis" to extract the factor whose characteristic is more than 2, orthogonal rotation processing was carried out by using the variance maximum method.

According to the entry deletion criteria of factor analysis (factor load less than 0.4 and dimension attribution difficult to interpret) [35], the question "I can easily understand most subjects, but understanding science is difficult for me" (S8) was deleted. The eighth question is obviously a subdimension of science interest, but after the EFA, the question was attributed to the dimension of mathematics interest, which is difficult to interpret, so the question was removed.

The researchers analysed the second exploratory factor to remove the data from the eighth question, and finally extracted five factors and retained 48 question items. The five-factor extraction is consistent with the recommendations of the gravel map test. The first factor was "21st-century skill confidence", which contained 11 subjects and had a factor interpretation rate of $17.267 \%$. The second factor was "STEM career interest", which contained 12 subjects with a factor interpretation rate of $12.939 \%$. The third factor was "engineering/technical interest", which contained 9 questions and had a factor interpretation rate of $12.527 \%$. The fourth factor was "science interest", which contained 8 questions with a factor interpretation rate of $12.056 \%$. The fifth factor was "mathematics interest", containing 8 questions with a factor interpretation rate of $10.389 \%$. The accumulative interpretation rate of five factors was $65.178 \%$, as shown in Table 3 .

Table 3. Exploratory factor analysis and reliability test of the STEM attitude scale for primary and secondary school students $(n=283)$.

\begin{tabular}{|c|c|c|c|c|c|}
\hline \multirow[b]{2}{*}{ Items } & \multicolumn{5}{|c|}{ Factors } \\
\hline & $\begin{array}{l}\text { 21st-Century Skill } \\
\text { Confidence }\end{array}$ & $\begin{array}{l}\text { STEM Career } \\
\text { Interest }\end{array}$ & $\begin{array}{l}\text { Engineering/Technology } \\
\text { Interest }\end{array}$ & Science Interest & $\begin{array}{c}\text { Mathematics } \\
\text { Interest }\end{array}$ \\
\hline $\mathrm{C} 5$ & 0.817 & & & & \\
\hline C6 & 0.784 & & & & \\
\hline $\mathrm{C} 10$ & 0.779 & & & & \\
\hline $\mathrm{C} 4$ & 0.777 & & & & \\
\hline $\mathrm{C} 7$ & 0.765 & & & & \\
\hline $\mathrm{C} 8$ & 0.759 & & & & \\
\hline C9 & 0.756 & & & & \\
\hline $\mathrm{C} 2$ & 0.732 & & & & \\
\hline $\mathrm{C} 11$ & 0.725 & & & & \\
\hline $\mathrm{C} 1$ & 0.650 & & & & \\
\hline C3 & 0.645 & & & & \\
\hline J6 & & 0.717 & & & \\
\hline $\mathrm{J} 2$ & & 0.707 & & & \\
\hline J9 & & 0.697 & & & \\
\hline $\mathrm{J} 10$ & & 0.682 & & & \\
\hline $\mathrm{J} 12$ & & 0.678 & & & \\
\hline J11 & & 0.669 & & & \\
\hline $\mathrm{J} 4$ & & 0.654 & & & \\
\hline $\mathrm{J} 7$ & & 0.650 & & & \\
\hline $\mathrm{J} 3$ & & 0.618 & & & \\
\hline $\mathrm{J} 1$ & & 0.602 & & & \\
\hline $\mathrm{J} 5$ & & 0.541 & & & \\
\hline $\mathrm{J} 8$ & & 0.449 & & & \\
\hline
\end{tabular}


Table 3. Cont.

\begin{tabular}{|c|c|c|c|c|c|}
\hline \multirow[b]{2}{*}{ Items } & \multicolumn{5}{|c|}{ Factors } \\
\hline & $\begin{array}{l}\text { 21st-Century Skill } \\
\text { Confidence }\end{array}$ & $\begin{array}{l}\text { STEM Career } \\
\text { Interest }\end{array}$ & $\begin{array}{c}\text { Engineering/Technology } \\
\text { Interest }\end{array}$ & Science Interest & $\begin{array}{c}\text { Mathematics } \\
\text { Interest }\end{array}$ \\
\hline ET4 & & & 0.769 & & \\
\hline ET5 & & & 0.767 & & \\
\hline ET3 & & & 0.719 & & \\
\hline ET1 & & & 0.708 & & \\
\hline ET6 & & & 0.694 & & \\
\hline ET2 & & & 0.645 & & \\
\hline ET9 & & & 0.641 & & \\
\hline ET7 & & & 0.633 & & \\
\hline ET8 & & & 0.515 & & \\
\hline S5 & & & & 0.764 & \\
\hline S2 & & & & 0.763 & \\
\hline S3 & & & & 0.745 & \\
\hline S6 & & & & 0.720 & \\
\hline $\mathrm{S} 4$ & & & & 0.701 & \\
\hline S7 & & & & 0.680 & \\
\hline S1 & & & & 0.656 & \\
\hline S9 & & & & 0.506 & \\
\hline M3 & & & & & 0.778 \\
\hline M5 & & & & & 0.744 \\
\hline M8 & & & & & 0.741 \\
\hline M1 & & & & & 0.716 \\
\hline M4 & & & & & 0.707 \\
\hline M7 & & & & & 0.677 \\
\hline M2 & & & & & 0.577 \\
\hline M6 & & & & & 0.570 \\
\hline Eigenvalue & 8.288 & 6.211 & 6.013 & 5.787 & 4.986 \\
\hline $\begin{array}{l}\text { Factor interpreta-tion } \\
\text { rate }\end{array}$ & $17.267 \%$ & $12.939 \%$ & $12.527 \%$ & $12.056 \%$ & $10.389 \%$ \\
\hline
\end{tabular}

Note: factor loads less than 0.4 are not displayed.

CFA is a verification of existing theoretical models and the degree of data fitting, which is achieved by comparing the difference between the covariance matrix of the hypothetical model and the covariance matrix of the sample data. The research team used the structural equation model (SEM), the other half of the sample data (283 copies) and Amos 24.0 statistical software for the multivariate normal test. The results showed that the absolute value of skew was within 2 and the absolute value of kurtosis was within 7 , which was in line with the univariate normal distribution. However, the CR value of the multivariate was 16.5220, which is greater than 5 but less than 49 , which is moderately abnormal and basically acceptable, as can be seen in Table 4 .

Table 4. Skewness and Kurtosis analysis of each dimension of the STEM attitude scale for primary and secondary school students.

\begin{tabular}{ccccccc}
\hline Variables & Min & Max & Skew & C.R. & Kurtosis & C.R. \\
\hline Mathematics interest & 1.000 & 5.000 & -0.343 & -2.354 & 0.085 & 0.292 \\
Science interest & 1.000 & 5.000 & -0.207 & -1.424 & 0.021 & 0.072 \\
Engineering/technology interest & 1.000 & 5.000 & -0.239 & -1.641 & -0.123 & -0.423 \\
21st-century skills self-confidence & 1.000 & 5.000 & -0.606 & -4.160 & 0.721 & 2.475 \\
STEM career interest & 1.000 & 4.000 & -0.122 & -0.836 & 0.203 & 0.698 \\
Multivariate & & & & & 16.434 & 16.522 \\
\hline
\end{tabular}

Amos 24.0 statistical software was used for CFA to test the five-factor structure proposed by EFA. This showed that the standardized factor load of each dimension of the 
STEM attitude scale is greater than 0.5 , the combined reliability coefficient (CR) is greater than 0.8 , and the average variance extraction value (AVE) is greater than 0.4 , indicating that the scale has good convergent validity.

The maximum likelihood method is used for parameter estimation, and the goodnessof-fit index (GFI), adjusted goodness-of-fit index (AGFI), comparative adaptation index (CFI), value-added adaptation index (IFI), and irregular adaptation index (TLI) are used for model fitting and identification to verify the fitting degree of the model. Based on the existing theoretical studies, the hypothesis model 1, high-order single factor model, is proposed, that is, the driving factors are generally explained by primary and secondary school students' learning interest in STEM as a driving factor. According to EFA results, the hypothesis model 2, low-order one-factor and high-order five-factor model, is proposed, that is, the first-order five factors are mathematics (IOM), science (IOS), engineering (IOET), 21st-century skills (COS), and STEM career interest (SCI), with the five factors freely correlated. Together, they explain the driving factors of primary and secondary school students' learning interest in STEM. Usually $\mathrm{x}^{2 /} \mathrm{df}<3$, indicates that the model meets the adaptation requirements; the root mean square error of approximation (RMSEA) $<0.05$ fit is good, $0.05-0.08$ fit is reasonable, $0.08-0.10$ fit is acceptable, and other fitting index must be above 0.09 , indicating a good fit, and greater than 0.08 is acceptable [36]. As shown in Table 5, each fitting index of the study is within the statistically acceptable range. Therefore, the Chinese version of the STEM attitude scale for primary and secondary school students has good structural validity.

Table 5. Fitting index of confirmatory factor analysis of the STEM attitude scale for primary and secondary school students $(n=283)$.

\begin{tabular}{ccccccc}
\hline $\mathbf{x}^{2} / \mathbf{d f}$ & RMSEA & GFI & CFI & IFI & TLI & AGFI \\
\hline 1.351 & 0.044 & 0.879 & 0.965 & 0.966 & 0.963 & 0.866 \\
\hline
\end{tabular}

Note: $x^{2}$, Chi-square; df, degrees of freedom; RMSEA, root mean-square error of approximation; GFI, mean goodness-of-fit index; CFI, comparative goodness-of-fit index; IFI, incremental fit index; TLI, Tucker-Lewis index; AGFI, adjusted goodness-of-fit index.

\subsection{Aggregation Validity}

The aggregation validity of the scale was tested by investigating the scores of each dimension of the STEM attitude scale for primary and secondary school students in the Chinese version and the correlation between the dimension scores and the total score. See Table 6 for results. The significance probability of each subdimension is less than 0.001 , and the correlation coefficient is between 0.460 and 0.685 , indicating that the subdimensions of the scale are moderately correlated. The square root of AVE of each subdimension is greater than the correlation coefficient of other factors, and the heterotrait-monotrait ratio of correlations (HTMT) of each subdimension is less than 0.85 , indicating that the scale has good discriminant validity [37], this is shown in Table 7. The correlation coefficient between each subdimension and the total score is between 0.718 and 0.860 , indicating that each subdimension of the scale is highly correlated with the total scale. 
Table 6. The extracted square root and correlation coefficient of the mean variance between each dimension and the total score of the STEM attitude scale for primary and secondary school students.

\begin{tabular}{cccccc}
\hline Categories & $\begin{array}{c}\text { Mathematics } \\
\text { Interest }\end{array}$ & $\begin{array}{c}\text { Science } \\
\text { Interest }\end{array}$ & $\begin{array}{c}\text { Engineering/ } \\
\text { Technology } \\
\text { Interest }\end{array}$ & $\begin{array}{c}\text { 21st-Century } \\
\text { Skills } \\
\text { Self-Confidence }\end{array}$ & $\begin{array}{c}\text { STEM Career } \\
\text { Interest }\end{array}$ \\
\hline $\begin{array}{c}\text { Mathematics } \\
\text { interest } \\
\text { Science interest } \\
\text { Engineering/ } \\
\text { technology } \\
\quad \text { interest }\end{array}$ & 0.720 & $0.490 *$ & 0.779 & & \\
$\begin{array}{c}\text { 21st-century skills } \\
\text { self-confidence } \\
\text { STEM career } \\
\text { interest }\end{array}$ & $0.504 *$ & $0.625 *$ & 0.793 & 0.681 & 0.695 \\
Total score & $0.460 *$ & $0.651 *$ & $0.685 *$ & $0.514 *$ & $0.788 *$ \\
\hline
\end{tabular}

Note: ${ }^{*} p<0.01$. The data at the bottom left of the diagonal are the correlation coefficient between the variables; the data on the diagonal are the square root of the mean variance extraction value (AVE) of the variable.

Table 7. HTMT analysis of various dimensions of the STEM attitude scale for primary and secondary school students.

\begin{tabular}{|c|c|c|c|c|c|}
\hline Categories & $\begin{array}{c}\text { Mathematics } \\
\text { Interest }\end{array}$ & Science Interest & $\begin{array}{l}\text { Engineering/ } \\
\text { Technology } \\
\text { Interest }\end{array}$ & $\begin{array}{c}\text { 21st-Century } \\
\text { Skills } \\
\text { Self-Confidence }\end{array}$ & $\begin{array}{l}\text { STEM Career } \\
\text { Interest }\end{array}$ \\
\hline Mathematics interest & 1 & & & & \\
\hline Science interest & 0.543 & 1 & & & \\
\hline $\begin{array}{l}\text { Engineering/technology } \\
\text { interest }\end{array}$ & 0.556 & 0.674 & 1 & & \\
\hline $\begin{array}{l}\text { 21st-century skills } \\
\text { self-confidence }\end{array}$ & 0.537 & 0.690 & 0.726 & 1 & \\
\hline $\begin{array}{l}\text { STEM career } \\
\text { interest }\end{array}$ & 0.513 & 0.623 & 0.679 & 0.547 & 1 \\
\hline
\end{tabular}

\subsection{Reliability Test}

The internal consistency analysis and split-half reliability test of the total table and each factor were carried out with the help of the tested samples. The results show that the Cronbach's $\alpha$ of the Chinese version of STEM is 0.967, and the internal consistency reliability of each factor is between 0.892 and 0.959 . The split-half reliability of each factor is between 0.927 and 0.957 . See Table 8 for details. It can be seen that the reliability of the Chinese version of the STEM attitude scale for primary and secondary school students is high.

Table 8. Confirmatory factor analysis of the STEM attitude scale for primary and secondary school students.

\begin{tabular}{cccccc}
\hline Factors & Items & Factor Loading & Cronbach's $\alpha$ & CR & \\
\hline & M1 & 0.581 & & \\
M2 & 0.641 & & & \\
Mathematics & M3 & 0.586 & 0.893 & \\
interest & M4 & 0.784 & & \\
& M5 & 0.540 & & \\
& M6 & 0.759 & & \\
\hline
\end{tabular}


Table 8. Cont.

\begin{tabular}{|c|c|c|c|c|c|}
\hline Factors & Items & Factor Loading & Cronbach's $\alpha$ & CR & AVE \\
\hline \multirow{8}{*}{ Science interest } & S1 & 0.733 & \multirow{8}{*}{0.924} & \multirow{8}{*}{0.925} & \multirow{8}{*}{0.607} \\
\hline & S2 & 0.790 & & & \\
\hline & S3 & 0.825 & & & \\
\hline & S4 & 0.772 & & & \\
\hline & S5 & 0.848 & & & \\
\hline & S6 & 0.778 & & & \\
\hline & S7 & 0.800 & & & \\
\hline & S9 & 0.671 & & & \\
\hline \multirow{9}{*}{$\begin{array}{l}\text { Engineering/technology } \\
\text { interest }\end{array}$} & ET1 & 0.798 & \multirow{9}{*}{0.938} & \multirow{9}{*}{0.938} & \multirow{9}{*}{0.629} \\
\hline & ET2 & 0.721 & & & \\
\hline & ET3 & 0.793 & & & \\
\hline & ET4 & 0.813 & & & \\
\hline & ET5 & 0.841 & & & \\
\hline & ET6 & 0.805 & & & \\
\hline & ET7 & 0.807 & & & \\
\hline & ET8 & 0.800 & & & \\
\hline & ET9 & 0.754 & & & \\
\hline \multirow{11}{*}{$\begin{array}{l}\text { 21st-century skills } \\
\text { self-confidence }\end{array}$} & $\mathrm{C} 1$ & 0.787 & \multirow{11}{*}{0.959} & \multirow{11}{*}{0.959} & \multirow{11}{*}{0.681} \\
\hline & $\mathrm{C} 2$ & 0.812 & & & \\
\hline & $\mathrm{C} 3$ & 0.831 & & & \\
\hline & $\mathrm{C} 4$ & 0.806 & & & \\
\hline & C5 & 0.862 & & & \\
\hline & C6 & 0.806 & & & \\
\hline & $\mathrm{C} 7$ & 0.876 & & & \\
\hline & $\mathrm{C} 8$ & 0.827 & & & \\
\hline & C9 & 0.856 & & & \\
\hline & C10 & 0.818 & & & \\
\hline & $\mathrm{C} 11$ & 0.792 & & & \\
\hline \multirow{12}{*}{$\begin{array}{l}\text { STEM career } \\
\text { interest }\end{array}$} & $\mathrm{J} 1$ & 0.775 & \multirow{12}{*}{0.917} & \multirow{12}{*}{0.910} & \multirow{12}{*}{0.483} \\
\hline & $\mathrm{J} 2$ & 0.786 & & & \\
\hline & $\mathrm{J} 3$ & 0.691 & & & \\
\hline & $\mathrm{J} 4$ & 0.504 & & & \\
\hline & J5 & 0.676 & & & \\
\hline & J6 & 0.600 & & & \\
\hline & J7 & 0.770 & & & \\
\hline & J8 & 0.591 & & & \\
\hline & J9 & 0.594 & & & \\
\hline & $\mathrm{J} 10$ & 0.815 & & & \\
\hline & $\mathrm{J} 11$ & 0.764 & & & \\
\hline & J12 & 0.736 & & & \\
\hline
\end{tabular}

4.5. Differences in STEM Attitudes of Primary and Secondary School Students in Different Groups 4.5.1. Gender

The researchers conducted statistical analysis on the survey samples to preliminarily understand the differences in STEM attitudes of primary and secondary school students of different genders and grades, as well as differences among students whose parents have reached various levels of academic qualifications in China. Independent sample $t$-test showed that except for 21st-century skill confidence $(p=0.739)$, there were significant gender differences in the areas measured: mathematics interest $(p=0.003)$, science interest $(p=0.012)$, engineering/technology interest $(p=0.000)$, and STEM career interest $(p=0.001)$, as shown in Table 9. Thus, the gender imbalance in STEM education still exists. 
Table 9. Independent sample $t$-test of gender impact on the STEM Attitude in Primary and Secondary Schools.

\begin{tabular}{|c|c|c|c|c|c|c|}
\hline \multicolumn{2}{|c|}{ Gender } & $\begin{array}{l}\text { Mathematics } \\
\text { Interest }\end{array}$ & $\begin{array}{l}\text { Science } \\
\text { Interest }\end{array}$ & $\begin{array}{l}\text { Engineering/Technology } \\
\text { Interest }\end{array}$ & $\begin{array}{l}\text { 21st Century Skills Self- } \\
\text { Confidence }\end{array}$ & $\begin{array}{l}\text { STEM Career } \\
\text { Interest }\end{array}$ \\
\hline \multirow{2}{*}{$\begin{array}{l}\text { Female } \\
(n=305)\end{array}$} & $\mathrm{M}$ & 3.363 & 3.404 & 3.356 & 3.855 & 2.616 \\
\hline & $\mathrm{SD}$ & 0.871 & 0.806 & 0.844 & 0.780 & 0.640 \\
\hline \multirow{2}{*}{$\begin{array}{c}\text { Male } \\
(n=261)\end{array}$} & $M$ & 3.580 & 3.578 & 3.664 & 3.878 & 2.794 \\
\hline & $\mathrm{SD}$ & 0.848 & 0.920 & 0.948 & 0.833 & 0.671 \\
\hline \multicolumn{2}{|c|}{$\mathrm{t}$} & -3.001 & -2.380 & -4.053 & -0.333 & -3.218 \\
\hline \multicolumn{2}{|c|}{$\mathrm{P}$} & 0.003 & 0.018 & 0.000 & 0.739 & 0.001 \\
\hline
\end{tabular}

Eccles has pointed out that "cultural milieu" plays an important role in all aspects of personal attitudes towards learning and career choices [38]. Some studies have pointed out that in real life, girls' STEM attitude is deeply affected by gender stereotypes, and they rarely choose STEM-related courses or careers [39]. Therefore, how to improve the gender difference of STEM attitudes of primary and secondary school students from the "cultural environment" needs to be further investigated.

\subsubsection{Grades}

Due to the heterogeneity of variance test, the researcher conducted an independent sample Kruskal-Wallis test on STEM attitudes of primary and secondary school students in different grades. Details are in Table 10. The results show that there was no significant difference in stem attitude between grade four and grade five students. In addition to STEM professional interest $(p=0.119)$, grade seven students' mathematics interest $(p=0.000)$, science interest $(p=0.001)$, engineering/technology interest $(p=0.034)$ and 21st century skill confidence ( $p=0.003$ ) were significantly higher than grade eight students. In addition, STEM vocational interest in primary school is generally higher than that in junior middle school. When students reach the ninth grade, their STEM interest, 21st-century skill self-confidence, and STEM career interest have decreased, for they face the pressure of either entering a senior high school, a secondary vocational school, or taking a job. In addition, with the increase in grade level, the complexity and difficulty of the content affects students' STEM attitude. Special attention should be paid to cultivate the STEM attitude of junior high school students.

Table 10. Independent sample nonparametric test for the influence of grade on STEM attitudes in primary and secondary schools.

\begin{tabular}{|c|c|c|c|c|c|c|c|}
\hline Categories & Grade & $\mathbf{N}$ & $\mathbf{M}$ & SD & $\mathrm{T}$ & $\mathbf{P}$ & $\begin{array}{c}\text { Combination of } \\
\text { Significant Differences } \\
\text { between Groups }\end{array}$ \\
\hline \multirow{6}{*}{ Mathematics interest } & 4 & 168 & 3.632 & 0.824 & \multirow{6}{*}{61.701} & \multirow{6}{*}{$0.00 *$} & \multirow{6}{*}{$1>5,2>5,4>5$} \\
\hline & 5 & 90 & 3.647 & 0.791 & & & \\
\hline & 7 & 21 & 3.363 & 0.833 & & & \\
\hline & 8 & 168 & 3.595 & 0.832 & & & \\
\hline & 9 & 119 & 2.916 & 0.821 & & & \\
\hline & Total & 566 & 3.463 & 0.867 & & & \\
\hline \multirow{6}{*}{ Science interest } & 4 & 168 & 3.642 & 0.849 & \multirow{6}{*}{44.291} & \multirow{6}{*}{$0.00 *$} & \multirow{6}{*}{$1>5,2>4,4>5$} \\
\hline & 5 & 90 & 3.753 & 0.652 & & & \\
\hline & 7 & 21 & 3.500 & 0.589 & & & \\
\hline & 8 & 168 & 3.470 & 0.930 & & & \\
\hline & 9 & 119 & 3.075 & 0.830 & & & \\
\hline & Total & 566 & 3.484 & 0.864 & & & \\
\hline
\end{tabular}


Table 10. Cont.

\begin{tabular}{|c|c|c|c|c|c|c|c|}
\hline Categories & Grade & $\mathbf{N}$ & $\mathbf{M}$ & SD & $\mathbf{T}$ & $\mathbf{P}$ & $\begin{array}{c}\text { Combination of } \\
\text { Significant Differences } \\
\text { between Groups }\end{array}$ \\
\hline \multirow{6}{*}{$\begin{array}{c}\text { Engineering/Technology } \\
\text { interest }\end{array}$} & 4 & 168 & 3.768 & 0.852 & \multirow{6}{*}{60.931} & \multirow{6}{*}{$0.00 *$} & \multirow{6}{*}{$\begin{array}{c}1>3,1>4,1>5,2>3,2 \\
>4,2>5,4>5\end{array}$} \\
\hline & 5 & 90 & 3.806 & 0.722 & & & \\
\hline & 7 & 21 & 3.190 & 0.557 & & & \\
\hline & 8 & 168 & 3.399 & 0.930 & & & \\
\hline & 9 & 119 & 3.076 & 0.919 & & & \\
\hline & Total & 566 & 3.498 & 0.906 & & & \\
\hline \multirow{6}{*}{$\begin{array}{l}\text { 21st century skills } \\
\text { self-confidence }\end{array}$} & 4 & 168 & 3.942 & 0.813 & \multirow{6}{*}{30.183} & \multirow{6}{*}{$0.00 *$} & \multirow{6}{*}{$1>5,2>5,4>5$} \\
\hline & 5 & 90 & 4.103 & 0.686 & & & \\
\hline & 7 & 21 & 3.662 & 0.662 & & & \\
\hline & 8 & 168 & 3.901 & 0.817 & & & \\
\hline & 9 & 119 & 3.565 & 0.796 & & & \\
\hline & Total & 566 & 3.866 & 0.804 & & & \\
\hline \multirow{6}{*}{$\begin{array}{l}\text { STEM career } \\
\text { interest }\end{array}$} & 4 & 168 & 2.892 & 0.611 & \multirow{6}{*}{54.132} & \multirow{6}{*}{$0.00 *$} & \multirow{6}{*}{$\begin{aligned} 1>3,1 & >4,1>5,2>3,2 \\
& >4,2>5\end{aligned}$} \\
\hline & 5 & 90 & 2.893 & 0.573 & & & \\
\hline & 7 & 21 & 2.516 & 0.429 & & & \\
\hline & 8 & 168 & 2.614 & 0.721 & & & \\
\hline & 9 & 119 & 2.429 & 0.610 & & & \\
\hline & Total & 566 & 2.698 & 0.660 & & & \\
\hline
\end{tabular}

Note: ${ }^{*} p<0.01$, in the comparison between groups, 1: Grade 4, 2: Grade 5, 3: Grade 1, 4: Grade 2, 5: Grade 3.

\subsubsection{Parents with Different Education Levels}

The researchers conducted an independent sample $t$-test on the STEM attitude of primary and secondary school students whose parents' have different educational backgrounds. Details are in Table 11. The results show that there were significant differences in STEM attitude between students with parents holding a bachelor's degree or above and students with parents' educational level below bachelor's degree. Students whose parents have a bachelor's degree or higher have significantly higher interest in mathematics ( $p=$ $0.000)$, science $(p=0.000)$, engineering/technology $(p=0.000)$, 21st-century skill confidence $(p=0.000)$, and STEM career interest $(p=0.000)$ than students whose parents' educational level is below bachelor's degree.

Table 11. Independent sample $t$-test of the influence of parents' different levels of education on STEM attitudes in primary and secondary schools.

\begin{tabular}{ccccccc}
\hline \multicolumn{2}{c}{ Highest Education Level } & Mathematics & $\begin{array}{c}\text { Science } \\
\text { Interest }\end{array}$ & $\begin{array}{c}\text { Engineering/ } \\
\text { Technology } \\
\text { Interest }\end{array}$ & $\begin{array}{c}\text { 21st Century } \\
\text { Skills Self- } \\
\text { Confidence }\end{array}$ & $\begin{array}{c}\text { STEM } \\
\text { Career } \\
\text { Interest }\end{array}$ \\
\hline $\begin{array}{c}\text { Below bachelor's degree } \\
(n=330)\end{array}$ & $\mathrm{M}$ & 3.307 & 3.366 & 3.347 & 3.761 & 2.610 \\
\hline $\begin{array}{c}\text { Bachelor's degree or above } \\
(n=236)\end{array}$ & $\mathrm{SD}$ & 0.812 & 0.805 & 0.827 & 0.743 & 0.620 \\
\hline & $\mathrm{M}$ & 3.681 & 3.649 & 3.708 & 4.012 & 2.822 \\
\hline & $\mathrm{SD}$ & 0.895 & 0.917 & 0.969 & -4.663 & -3.694 \\
\hline $\mathrm{P}$ & & -3.001 & -5.094 & -3.801 & 0.000 & 0.000 \\
\hline
\end{tabular}


It can be seen that the more education parents have, the more positive students' STEM attitude is, and parents can affect their children's STEM learning interest to a certain extent. Studies have shown that parents' education level can predict children's future achievements and can significantly predict children's academic achievements and behavioural performance. Parents' education level has a direct impact on children's achievements [40]. Therefore, the improvement of STEM attitudes of students with low parental education level should be paid attention to.

\section{Discussion and Conclusions}

Petousi and Sifaki (2020) argue that any research misconduct may cause a loss of trust in the science, and in turn may lead to some socio-scientific issues [41]. Therefore, it is meaningful to discuss the validity and reliability of the STEM interest scale, and how students' STEM interests and skill confidence were affected significantly by their gender, grades, and parental educational levels.

\subsection{STEM Interest Scale Validity and Reliability}

The analysis of the project shows that the difference between the high and low scores of each item of the scale is significant, which indicates that each item of the scale has good discrimination. Item analysis shows that there are significant differences in the scores of each item of the scale, indicating that each item of the scale has good discrimination. At the same time, the content validity and aggregation validity of the scale were tested. The test of content validity shows that the evaluation of the scale by the members of the expert group is consistent, and the content validity of the Chinese version of the STEM attitude scale is better. The test of aggregate validity also shows that the Chinese version of the STEM attitude scale had high correlation subdimensions with the total scale, and the aggregate validity of the scale was good. The first EFA deleted the question "I can easily understand most subjects, but understanding science is difficult for me" in the dimension of science interest. This is in line with the item deletion standard of factor analysis in statistical analysis and is also related to the nature of science disciplines in primary and secondary schools in China. In February 2017, the Ministry of Education issued the primary school science curriculum standard for compulsory education. Primary school science is divided into four fields: material science, life science, earth and universe science, technology, and engineering [42]. Similarly, according to the current junior middle school science curriculum standard (2011 edition), junior middle school science is divided into seven parts: scientific inquiry, life science, material science, earth and universe, science, technology, society, and environment. Because the content of science subjects in primary and secondary schools is relatively extensive, students cannot make consistent judgements on the difficulty of understanding science subjects. Therefore, this question does not have statistical and practical significance in the process of Sinicization, so it was deleted.

CFA verified the five factors obtained from EFA, and each fitting index was within the acceptable range of measurement, indicating that the structural validity of the Chinese version of the STEM attitude scale was good. Thus, the Chinese version of this scale has been preliminarily formed. The reliability and validity of the scale are reasonable and in line with the actual situation in China. It can be used for empirical research to evaluate the STEM attitude of Chinese primary and secondary school students. At the same time, the preliminary use of this scale also shows that the STEM attitude of Chinese primary and secondary school students is affected by gender, grade, and the highest educational background of their parents.

\subsection{Students' STEM Interest and Skill Confidence Significantly Decreased with Increasing Grade Levels}

This phenomenon may be related to two characteristics of the STEM discipline. Firstly, primary school knowledge is relatively simple, and easy to understand. Pupils become highly interested in science and technology when they are exposed to exploring resources within the environment in the course of learning [43]. The decline of interest with increasing 
grade levels in all disciplines is inevitable [44]. With higher grade levels, the learning content with strong structure and hierarchy is more complex and abstract, as a result, the more difficulties students encounter in learning, the less success they have, which is more likely to lead to a low level of learning attitude and a decline of 21st-century skills confidence. The grade differences in learning confidence gradually increase with the improvement of the developmental level [45]. Secondly, study at the primary and middle stage is highly cumulative. The previous stage of learning directly affects the latter stage of learning. In addition, as grade levels increase, more students don't think knowledge is directly useful in life, which can have a negative impact on students' learning activities and self-confidence in skills [44]. Duan also finds that the higher the grade is, the lower the proportion of students is in a good learning mood, and the proportion of students with a positive learning attitude decreases significantly [46].

In view of the above situation, the authors believe that lower grade students spend relatively less time on study and have comparatively more time on developing their pure interests and motivation in STEM, while higher grade students are more utilitarian by associating study greatly with short-term learning goals such as entering a higher school, resulting in greater psychological pressure and less STEM interests.

\subsection{Boys' STEM Interests and STEM Career Interest Are Significantly Higher Than Those of Girls}

The results of this study show that boys scored significantly higher than girls in terms of STEM interests and STEM career interest except in 21st century skills confidence. A variety of factors can cause gender differences in STEM interest. Gunderson et al. found that parents and teachers often have gender biases in their children's math ability expectations, which affects children's mathematics attitudes [47]. Shapiro et al. have shown that stereotypes can undermine mathematics attitudes, which in turn undermine girls interest and performance in the STEM field [48].

Zhou et al. found that the difference in STEM interests among elementary school students are not significant, but after a comprehensive STEM project, there are gender differences in the effect of improving STEM interest [39]. The difference between the results of this study and the results of Zhou may be due to the inconsistency of the study area. Zhou conducted research in Guangdong Province in southern China, while this research was conducted in eastern and northern China. However, gender differences in STEM interests do exist. A comparison of the two studies reveals that, on the one hand, the gender gap in STEM attitudes may be improved by the "cultural environment" [49], on the other hand, only a suitably comprehensive STEM project can improve the STEM interest of girls; this requires further development and study.

\subsection{More Educated Parents, More Positive Students' STEM Interests}

The research results of Xiao Wei et al. indicate that there is no significant correlation between a guardian's highest education level and a students' interest in science [50]. The reason that the results of this study are inconsistent with those of Xiao Wei et al. may be that the respondents selected by Xiao Wei et al. were 15-year-old students in four middle schools in Shanghai, while the respondents in this study were mainly junior middle school students in Jiangsu and Shandong, and there may be differences among students in different grades.

Zhang Yinghua et al. conducted a study in Taiwan in the early 1990s which found that parents' educational background has a great influence on their children's junior high school graduation, but it has little influence on their children's senior high school graduation [51]. This also explains to some extent the discrepancy between the results of this study and those of Xiao Wei. This may be because the highest education of guardians has a significant influence on junior high school students, while the influence on senior high school students is small.

Based on the above test and analysis, the conclusions of this study are as follows: (1) One item is deleted and 48 items are retained in the Chinese version of the STEM attitude 
scale. (2) The Chinese version of the STEM attitude scale presents a five-dimensional structure among Chinese primary and secondary school students, which are mathematics interest, science interest, engineering/technology interest, 21st-century skill confidence, and STEM career interest. The research conforms to both the EFA and CFA inspection models. (3) The Chinese version of the STEM attitude scale has good content validity, structural validity, aggregation validity. (4) The Chinese version of the STEM attitude scale has good reliability. (5) It can further explore the relationship between the STEM interest, 21st-century skill confidence, and STEM career interest of primary and secondary school students. This research also shows that students' STEM interests and STEM career interest clearly varied along gender, grade, and parental education levels, students can be encouraged to improve their interests if those elements are carefully examined.

\section{Limitations and Further Research Suggestions}

Due to the limited resources, the survey samples only come from Zhejiang, Shanghai, Shandong, and Liaoning, and there is no larger-scale survey. In validity analysis, the factor load of J8 is not 0.60 and above. With limited samples, it is very difficult to make better improvements. The follow-up research can expand the sample size, adopt diversified research methods, conduct more in-depth tests on the scale, investigate the conditions and mechanism of the impact of STEM learning attitudes of Chinese primary and middle school students, and compare and discuss results with the research of other countries. In addition, the reasons that boys scored significantly higher than girls in almost all of the STEM interests except 21st century skills confidence also deserve to be studied.

\section{Ethics Approval and Consent to Participate}

Petousi and Sifaki (2020) state that "scientists have a moral obligation towards society", and "public trust in science is grounded on scientists" moral obligation to society" [49]. As social science researchers, we also have the obligation to report research protocols. In this manuscript, they were approved by the ethical committee of the Institute of Psychology and Brain Science, Zhejiang Normal University (IRB Number: ZJNUPSY2021039), and informed consent was obtained from all student participants.

Author Contributions: Conceptualization, Y.Z. and Y.S.; methodology, Y.Z.; software, J.L.; validation, Q.X. and Y.Z.; formal analysis, Q.X. and J.L.; investigation, Y.Z. and Q.X.; resources, J.L.; data curation, J.L.; writing—original draft preparation, Y.Z.; writing—review and editing, Q.X. and Y.S.; visualization, J.L.; supervision, Y.Z.; project administration, Y.Z.; funding acquisition, Y.Z. All authors have read and agreed to the published version of the manuscript.

Funding: This research was the result of Boutique Online Open Courses, funded by Open Research Fund of College of Teacher Education, Zhejiang Normal University, grant number JYKF21015, and the APC was also funded by the self-funded project of Institute of African Studies Zhejiang Normal University, which is also Zhejiang Key Research Base of Philosophy and Social Sciences.

Institutional Review Board Statement: All procedures performed in this study involving human participants were in accordance with the guidelines of the Declaration of Helsinki, and approved by the Committee on Ethics and Human and Animal Protection of the Institute of Psychology and Brain Science, Zhejiang Normal University (protocol code ZJNUPSY2021039, 10 March 2019). The ethics committee sated that "based on your statement, your research plan meets the relevant requirements of this committee, the investigation involved in your research is safe and risk-free, so it has been approved by this committee, provided that the research methods you stated cannot be changed. Thank you for your professional spirit of being prudent and responsible for the ethical issues in your research".

Informed Consent Statement: Written informed consent has been obtained from all participants to publish this paper. 
Data Availability Statement: The data presented in this study are available in article. Detailed data is available from the first author on reasonable request. The data are not publicly available due to both restrictions, e.g., privacy or ethical and our promise of not disclosing the more specific details such as students' schools, their parental education levels.

Conflicts of Interest: The authors declare no conflict of interest.

\section{References}

1. Bureau of Labor Statistics. Occupational Outlook Handbook, 2010-2011 ed.; US Department of Labor: Washington, DC, USA, 2010.

2. Ministry of Education of the People's Republic of China. PISA 2018 Evaluation Results Were Officially Released; Ministry of Education of the People's Republic of China: Beijing, China, 2019.

3. Ruan, K. Research on the characteristics of middle school students' interest. Sci. Soc. Psychol. 2003, 18, $109-112$.

4. Unfried, A.; Faber, M.; Stanhope, D.S.; Wiebe, E. The development and validation of a measure of student attitudes toward science, technology, engineering, and math (S-STEM). J. Psychoeduc. Assess. 2015, 33, 622-639. [CrossRef]

5. Shi, R. Social Psychology; Shanghai People's Publishing House: Shanghai, China, 1986; p. 136.

6. Eccles, J.S.; Wigfield, A. Motivational beliefs, values, and goals. Ann. Rev. Psychol. 2002, 53, 109-132. [CrossRef] [PubMed]

7. Zimmerman, B.J.; Kitsantas, A. Developmental phases in self-regulation: Shifting from process goals to outcome goals. J. Educ. Psychol. 1997, 89, 29-36. [CrossRef]

8. Kidd, G.; Naylor, F. The predictive power of measured interests in tertiary course choice: The case of science. Aust. J. Educ. 1991, 35, 261-272. [CrossRef]

9. Kier, M.W.; Blanchard, M.R.; Osborne, J.W.; Albert, J.L. The development of the STEM career interest survey (STEM-CIS). Res. Sci. Educ. 2014, 44, 21. [CrossRef]

10. Mahoney, M.P. Students' attitudes toward STEM: Development of an instrument for high school STEM-based programs. J. Technol. Stud. 2010, 36, 24-34. [CrossRef]

11. Faber, M.; Unfried, A.; Wiebe, E.N.; Corn, J.; Townsend, L.W.; Collins, T.L. Student attitudes toward STEM: The development of upper elementary school and middle/high school student surveys. Presented at the 120th ASEE Annual Conference \& Exposition, Atlanta, GA, USA, 23-26 June 2013.

12. Dong, C. Research on Student Ability Evaluation Based on STEM Project Learning. Master's Thesis, Tianjin Normal University, Tianjin, China, 2017.

13. Fan, Y.; Zhou, D.; Yang, J.; Wang, J. A study on the evaluation of student engagement in project-oriented STEM teaching. Mod. Educ. Technol. 2018, 28, 121-126.

14. Zhang, Y.; Li, X.; Huang, J.; Zhang, Y.Y.; Fu, Y.; Wang, J.; Mei, L. The impact of a design-based integrated STEM teaching on students' interdisciplinary attitude. China Educ. Technol. 2018, 7, 81-89.

15. Li, W.; Bai, W. Research on student participation in reflective asynchronous e-learning model. Distance J. 2011, 3, 14-20.

16. Xia, X.; Dong, Y.; Bai, Y. An important experience of American STEM for science education in primary and secondary schools for China. J. Southeast Univ. (Philos. Soc. Sci. Ed.) 2016, 18, 169-171. [CrossRef]

17. Chen, H. On the mathematical model of "engagement" in classroom teaching. Res. Educ. Sci. 2001, 5, 31-32.

18. Wang, J.; Deng, C.Y. Developing STEM classroom teaching assessment scale based on group cooperative learning: Taking middle school biology "chromosome mode" as an example. Biol. Notif. 2017, 52, 8-11.

19. Yan, Y.; Wang, W. Comparison and optimization of STEM curriculum quality at home and abroad under the perspective of interdisciplinary integration. Mod. Distance Educ. Stud. 2020, 32, 39-47.

20. $\mathrm{Hu}, \mathrm{G} . ; \mathrm{Xu}, \mathrm{B}$. The relationship between learning self-efficacy, learning strategies and academic achievement in middle school students. J. Zhejiang Univ. (Sci. Ed.) 2003, 43, 477-480.

21. He, T.; Gan, Y. The relationship between learning self-efficacy and academic level among middle school students. Chin. J. Health Psychol. 2011, 19, 197-199.

22. Bian, Y. Compiling the perceived academic self-efficacy scale. Psychol. Sci. 2004, 27, 1218-1222.

23. Chen, K.; Chen, X.; Chen, Y. Middle school students' STEM learning attitude research-Based on the survey of six STEM pilot schools in Jiangsu Province. J. Chin. Audio-Vis. Educ. 2019, 3, 92-102.

24. Fraser, B.J. Development of a test of science-related attitudes. Sci. Educ. 1978, 62, 509-515. [CrossRef]

25. Williams, K.; Kurtek, K.; Sampson, V. The affective elements of science learning: A questionnaire to assess and improve student attitudes toward science. Sci. Teach. 2011, 78, 40-45.

26. Miller, R.B.; Greene, B.A.; Montalvo, G.P.; Ravindran, B.; Nichols, J.D. Engagement in academic work: The role of learning goals, future consequences, pleasing others, and perceived ability. Contemp. Educ. Psychol. 1996, 21, 388-422. [CrossRef]

27. Erkut, S.; Marx, F. 4 Schools for WIE (Evaluation Report); Center for Research on Women, Wellesley College: Wellesley, MA, USA, 2005; Available online: http:/ /www.coe.neu.edu/Groups/stemteams/evaluation.pdf (accessed on 8 January 2021).

28. The William and Ida Friday Institute for Educational Innovation. Governor Perdue's North Carolina Student Learning Conditions Survey (SLCS): Survey Implementation Study; Friday Institute for Educational Innovation: Raleigh, NC, USA, 2011.

29. Friday Institute for Educational Innovation. Middle and High School STEM-Student Survey; Friday Institute for Educational Innovation: Raleigh, NC, USA, 2015.

30. Yildirim, B.; Selvi, M. Adaptation of STEM Attitude Scale to Turkish. Electron. Turk. Stud. 2015, 10, 23. 
31. Benek, I.; Akcay, B. Development of STEM attitude scale for secondary school students: Validity and reliability study. Int. J. Educ. Math. Sci. Technol. 2019, 7, 32-52. [CrossRef]

32. Fouad, N.A.; Smith, P.L. A test of a social cognitive model for middle school students: Math and science. J. Couns. Psychol. 1996, 43, 338-346. [CrossRef]

33. Brotman, J.S.; Moore, F.M. Girls and science: A review of four themes in the science education literature. J. Res. Sci. Teach. 2008, 45, 971-1002. [CrossRef]

34. Shi, J.; Mo, X.; Sun, Z. Content validity index in scale development. J. Cent. South Univ. Med. Sci. 2012, 37, 152-155.

35. Wu, M. Questionnaire Statistical Analysis Practice-SPSS Operation and Application; Chongqing University Press: Chongqing, China, 2010.

36. Wu, M. Structural Equation Model-Operation and Application of Amos; Chongqing University Press: Chongqing, China, 2010.

37. Hair, J.F.; Hult, G.T.M.; Ringle, C.M.; Sarstedt, M. A Primer on Partial Least Squares Structural Equation Modeling (PLS-SEM), 2nd ed.; Sage: Thousand Oaks, CA, USA, 2017.

38. Eccles, J.S. Understanding educational and occupational choices. J. Soc. Issues 2011, 67, 5. [CrossRef]

39. Master, A.; Cheryan, S.; Meltzoff, A.N. Computing whether she belongs: Stereotypes undermine girls' occupational choices: Applying the Eccles et al. mode. J. Educ. Psychol. 2016, 108, 424-437. [CrossRef]

40. Li, Y.; Liu, L.; Liu, L. On the effects of parents' educational backgrounds and parenting behaviors on preschoolers' learning ability and problem behaviors. Chin. J. Spec. Educ. 2015, 5, 76-83.

41. Ministry of Education of the People's Republic of China. Science Curriculum Standards for Primary Schools in Compulsory Education. 2019. Available online: http:/ / www.moe.gov.cn/srcsite/A26/s8001/201702/W020170215542129302110.pdf (accessed on 12 November 2021).

42. Ayua, G.A.; Ode, G.O. Environmental Exploration and Its Influence on Development of Pupils' Interest in Basic Science and Technology in Primary Schools in Oju, Benue State. 2015. Available online: https://www.researchgate.net/publication/337167429 (accessed on 12 November 2021).

43. Krapp, A. Structural and dynamic aspects of interest development: Theoretical considerations from an ontogenetic perspective. Learn. Instr. 2002, 12, 383-409. [CrossRef]

44. Duan, P.Y. Grade Differences of non-intelligence factors in primary and middle school students-Analysis based on unconditional quantile regression. In Proceedings of the Academic Annual Meeting 2015; Beijing Institute of Educational Sciences: Beijing, China, 2015; pp. 49-58. Available online: https:/ / d.wanfangdata.com.cn/conference/8726771 (accessed on 12 November 2021).

45. Verschaffel, L.; Corte, E.D.; Lasure, S. Realistic considerations in mathematical modeling of school arithmetic word problems. Learn. Instr. 1994, 4, 273-294. [CrossRef]

46. Gunderson, E.A.; Ramirez, G.; Levine, S.C.; Beilock, S.L. The Role of Parents and Teachers in the Development of Gender-Related Math Attitudes. Sex Roles 2012, 66, 153-166. [CrossRef]

47. Shapiro, J.R.; Williams, A.M. The Role of Stereotype Threats in Undermining Girls' and Women's Performance and Interest in STEM Fields. Sex Roles 2012, 66, 175-183. [CrossRef]

48. Zhou, S.-N.; Zeng, H.; Xu, S.-R.; Chen, L.-C.; Xiao, H. Exploring changes in primary students' attitudes towards science, technology, engineering and mathematics (stem) across genders and grade levels. JBSE 2019, 18, 466-480. [CrossRef]

49. Petousi, V.; Sifaki, E. Contextualising Harm in the Framework of Research Misconduct. Findings from Discourse Analysis of Scientific Publications. Int. J. Sustain. Dev. 2020, 23, 149-174. [CrossRef]

50. Xiao, W. Cross-Cultural Research on Science Interests of 15-Year-Olds Based On PISA. Ph.D. Thesis, Shanghai Normal University, Shanghai, China, 2010. [CrossRef]

51. Zhang, Y.H.; Xue, C.T.; Huang, Y.Z. Educational Diversion and Socio-Economic Status; Education Reform Review Committee: Taiwan, China, 1995. 